was "Papa", perhaps arising from the paternal way in which he put us right about anything that had to do with radioactivity. But he was a very young father of a family and extremely unconventional. When things were going well, and new discoveries were coming out at the rate of about one a week, a tune recognizable by the elect as "Onward, Christian Soldiers" could be heard accompanying the Professor's steps along the corridors: when things were going less well another tune, no less holy, held sway.

It must not be thought that his interests were limited to radioactivity, or to any other particular branch of physics. I well remember him crossexamining A. D. Fokker about relativity, and any other visitor had to tell him all about the work in which he, the visitor, was expert. The theme of the laboratory in the few years before the Great War was, however, the structure of the nuclear atom, which he had put forward in 1911. In the laboratory during this period were Niels Bohr, H. G. J. Moseley, C. G. Darwin, J. Chadwick, H. Geiger, H. R. Robinson, J. M. Nuttall, E. Marsden, D. C. H. Florance, J. A. Gray, R. W. Boyle, H. B. Boltwood and A. Kovarik, to quote a few remembered names. Those were good days. Other great men will, no doubt, arise, but it is unlikely that any of us who worked with him in those days will live to see another such genius at the height of his powers, the leader and friend of such a school.

E. N. Da C. ANDrade.

LORD RUTHERFORD's death is a calamity for the Department of Scientific and Industrial Research. In the seven years during which he has been chairman of the Advisory Council, his influence has made itself felt throughout the Department. His broad sympathies, lively imagination, and deep insight equipped him in a wholly exceptional way to direct and strengthen the links between the Department and industry. It was an article of faith with him that the future of Great Britain depends upon the effective use of science by industry. It was this faith which induced him, a man of the highest attainment in the field of pure scientific research, to devote himself, as he did unreservedly, to our work. The development of the research association movement, now taking place, owes much to his foresight, sympathy and advocacy. Equally stimulating was his influence on the scientific work of the Department. In our counsels he leaves a blank which cannot be filled; and the loss of his unsparing service, his genial personality, and his warmhearted encouragement, may well fill the stoutest heart with dismay.

F. E. Sмiтн.

\title{
The Funeral of Lord Rutherford
}

$\mathrm{W}^{\mathrm{r}}$ ITHIN the ancient walls of Westminster Abbey and in the presence of a large gathering of men eminent in many walks of life, at noon on Monday, October 25, a typical English autumn day, the last remains of Lord Rutherford were laid to rest in the Nave near the graves of Newton, Kelvin, Darwin and Sir John Herschel. Thus another link was forged binding the Empire together, for Rutherford was the first man of science born in the overseas dominions to be buried in the Abbey. The honour thus accorded him is fitting recognition of the place he held among his fellows, and the memorable service at his burial, in its simplicity, beauty and dignity, was in keeping with the passing of a man of singleness of purpose whose whole life had been devoted to unravelling the secrets of Nature. There was no pomp or pageantry such as is seen at the burial of our great naval and military leaders, no word was said of his life or achievements, but a quiet air of sincerity pervaded the whole scene and left an indelible impression that it was all as he would have wished.

Among the large congregation, H.M. the King was represented by Lord Fortescue (Lord in Waiting). The Prime Minister was represented by Mr. G. P. Humphreys-Davies, the Lord Chancellor by Mr. Vernon Harington. Lord Halifax (Lord President of the Council), Lord Swinton (Secretary of State for Air), Sir Samuel Hoare (Secretary of State for Home Affairs), Sir Thomas Inskip (Minister for Co-ordination of Defence), Earl Baldwin and Mr. Ramsay MacDonald were present. Rear-Admiral A. Bromley represented the Secretary of State for Dominion Affairs and Admiral of the Fleet Lord Chatfield represented the Admiralty.

The ten pall-bearers were the High Commissioner for New Zealand, Prof. H. R. Dean (Vice-Chancellor of the University of Cambridge), Lord Dawson of Penn (president of the Royal College of Physicians), Sir William Bragg (president of the Royal Society), Sir Edward Poulton (president of the British Association), Prof. A. S. Eve, of McGill University, Prof. E. D. Adrian, of Trinity College, Cambridge, Sir Frank Smith, of the Department of Scientific and Industrial Research, Prof. W. L. Bragg, of the University of Manchester, and Sir George Lee, president of the Institution of Electrical Engineers. 
The service began with the singing of the sentences "I am the resurrection and the life . . ." while the coffin containing the urn with the ashes was borne slowly through the Nave and Choir to the bier placed in front of the Sanctuary and beneath the Lantern. Then followed the singing of the 23rd Psalm, the reading of Ecclesiasticus, xliv, 1-14, prayers and the hymns "The King of Love my Shepherd is" and "Praise, my soul, the King of Heaven". With the congregation standing, the coffin was then carried back to the Nave, followed by the mourners and chief representatives, and the committal took place. Owing to the recent death of the Dean, the Right Rev. W. Foxley Norris, the service was conducted by the Sub-Dean, Canon V. F. Storr, and it was his voice the congregation last heard as he pronounced the Blessing. The service was brought to an end with the organist playing Harwood's Requiem Aiternam. After the departure of the chief mourners, those present were permitted to file past the flowerstrewn spot where the urn rested, and above which will be placed the slab bearing the name of Rutherford.

On this occasion it is of interest to recall something of the other eminent men of science buried or commemorated in the Abbey; for as Dean Stanley wrote, the characteristic of Westminster Abbey which most endears it to the nation is the fact that it is the resting place of famous Britons, from every rank and creed, and every form of mind and genius. The earliest connexion of the Abbey with modern science and with the Royal Society goes back to the seventeenth century, when Sir Robert Moray, the first president of the Royal Society, was buried in the centre of the South Transept at the expense of Charles II. He died in 1673. Two years later, Dr. Thomas Willis, one of the earliest professors of natural philosophy at Oxford, was buried in the Abbey, and his interment was followed in 1677 by that of Isaac Barrow, the first Lucasian professor at Cambridge and the Master of Trinity. Both his grave and monument are in Poets' Corner. Just half a century separate the burials of Barrow and of Newton; but in the interval Dean Sprat, the first historian of the Royal Society, was buried in St. Nicholas's Chapel, and Thomas Tompion, 'father' of English clockmakers, was buried in the centre of the Nave.

Newton died on March 20, 1726 (O.S.) or March 31, 1727 (N.S.). For several days his body lay in state in the Jerusalem Chamber and then was buried on the south side of the Nave near the Choir. "His countrymen honoured him in his lifetime," wrote Voltaire, who was in London, "and interred him as though he had been a king who had made his people happy." Though there are memorials to men of science in many parts of the Abbey, it is around the grave and monument of Newton that the greatest number are to be found. Just in front of the monument are the tablets to Kelvin, Maxwell and Faraday, a little farther off are the gravestones of Telford and Robert Stephenson, while in the grave of Tompion lies also the body of his pupil and successor "Honest" George Graham, who on November 24, 1751, at night, was brought from his house in Fleet Street and laid with his master. To the north of Newton's grave, in the Aisle, are the graves of Darwin and Herschel, and a little farther to the west those of Lyell and John Hunter. Like Boyle, Hunter was first buried in St. Martin-in-the-Fields. Boyle's grave was lost sight of through the rebuilding of the church, but Hunter's coffin in the vaults of the new church was discovered by Frank Buckland, and through the action of the Royal College of Surgeons in 1859, was removed to the Abbey.

Also in the north aisle, but to the east of the grave of Darwin, are the eight memorials clustered around the tomb of Sir John Thynne, a zealous Sub-Dean of the Abbey. Here in 1888 was placed the medallion of Darwin, and beside that are now memorials to Joule, John Couch Adams, Sir Joseph Hooker, Alfred Russel Wallace, Sir George Gabriel Stokes, Lord Lister and Sir William Ramsay. The ten windows lighting the aisle are also memorials, and on some of them are to be found the names of Richard Trevithick, Isambard Kingdom Brunel, Robert Stephenson, Lord Kelvin, Sir Benjamin Baker and Sir John Wolfe-Barry. There were once windows to the memory of Joseph Locke and Sir William Siemens, but these have been removed.

Of the other memorials in various parts of the Abbey, the group in St. Andrew's Chapel is the most interesting, for here, beside the statue of Telford, are the tablets to Sir Humphry Davy, Thomas Young, Dr. Matthew Baillie the anatomist, Sir James Simpson and Lord Rayleigh, and also the monument to Sir John Franklin. Not far away, in St. Paul's Chapel, is to be found Chantrey's great statue of Watt, whilst elsewhere are to be found the graves or monuments of Sir William Spottiswoode, Sir John Pringle and Martin Folkes, three presidents of the Royal Society, John Woodward and Dean Buckland, Major James Rennell, Sir Stamford Raffles and the young Lancashire clergyman and astronomer Jeremiah Horrocks, who on November 24, 1639, was the first to observe a transit of Venus. Horrocks died in 1641 , but at the time of the transit of $1874 \mathrm{a}$ memorial, placed within that of Newton's nephew, John Conduitt, at the west end of the Nave, was erected with an inscription upon it by Dean Stanley. 